\title{
Meseron Therapy and Christian Counselling: A Synergy
}

\author{
Alfred Awaritefe \\ Department of Behavioural Studies, Faculty of Social Sciences, Redeemer's University, Osun State, Nigeria \\ Bede C. Akpunne* \\ Department of Behavioural Studies, Faculty of Social Sciences, Redeemer's University, Osun State, Nigeria \\ Olutope E. Akinnawo \\ Department of Behavioural Studies, Faculty of Social Sciences, Redeemer's University, Osun State, Nigeria \\ Deborah F. Onisile \\ Department of Nursing, Faculty of Basic Medical Sciences, Redeemer's University, Osun State, Nigeria \\ Ibukunoluwa B. Bello \\ Department of Behavioural Studies, Faculty of Social Sciences, Redeemer's University, Osun State, Nigeria \\ Oluseyi A. Alakija \\ Department of Behavioural Studies, Faculty of Social Sciences, Redeemer's University, Osun State, Nigeria
}

\begin{abstract}
Christian Counselling (CC) is the practice of talking with individuals, couples, and families to increase their understanding of emotional and religious conflicts and to help resolve problems using Christian religious injunctions and other related resources. Meseron Therapy (MT) was developed in accordance with the Nigerian belief in the power, potency and meaning of spoken words and its consequences. MT entails rejecting negativities and accepting the positives, with the techniques of MT reflecting a cognitive orientation. MT and CC approaches have several common grounds. The basic assumptions of MT such as the power of the spoken words to sensitize action, the ignition of man's inherent potential for change, replacement of a negative status quo with constructive actions and the view of man as a striving creature all have Biblical support. Also, MT's views on human nature and the causes of psychological disturbance agree with Christian teachings and beliefs. Application of Meseron therapeutic techniques and procedures to $\mathrm{CC}$ can be done by using Biblical teachings to enable clients sustain good health, encouraging the good use of endowments, assisting client in mental restructuring through motivation to strive, building and encouraging possibility thinking, enabling the clients to reject distractions from goal accomplishments and getting clients to say it right and synergize their thoughts, words and actions.
\end{abstract}

Keywords: Christian Counselling, Meseron Therapy, Synergy.

DOI: $10.7176 /$ RHSS/10-8-03

Publication date: April $30^{\text {th }} 2020$

\subsection{INTRODUCTION}

Meseron Therapy is a psychological treatment approach developed in Nigeria by Awaritefe in 1995 (Awaritefe, 1995, 1997, 2004; Ofovwe, 2005). The term 'Meseron' was adopted from the Urhobo language (the language of the Urhobo people of Delta State, Nigeria) which means "I reject/refuse." This therapy was developed in accordance with the Nigerian belief in the power of spoken words - its potency meanings and consequences; therefore leading to the rejection of the negatives while accepting the positives. The techniques of Meseron reflect a cognitive orientation requiring mental restructuring from clients hence, it is a form of cognitive therapy (Awaritefe and Ofovwe, 2007). It is also considered as a motivational theory because it affirms the need for man to strive for a desirable goal using inherent potentials and attributes.

Meseron Therapy affirms the following: first, that negative thoughts can be altered and made positive. Negative thoughts are at the root of most psychological disturbances. Secondly, that to correct an undesirable situation, covert actions must be taken at the level of thought. Finally, overt actions must be taken in the form of words and deeds.

According to Awaritefe, Akpunne and Olarinoye (2018), one of the main focus of Meseron therapy is correcting faulty thinking. Man continues in psychological disturbance because they say the wrong things, and since what one says or what is said about one which one believes may affect one's thoughts and behaviour, then one must correct the wrong speaking by rejecting wrong, unwholesome and negative confessions about self as well as such words spoken to them by others to overcome psychological disturbance (Awaritefe et al, 2018). 


\subsection{Basic Assumptions of Meseron Therapy}

The four basic assumptions of Meseron Therapy are:

i. the power of the spoken word to sensitize action;

ii. the inherent potential for change present in man;

iii. the replacement of a negative status quo with constructive action and

iv. finally, that man is a striving creature.

\subsection{Defining Christian Counselling}

Christian Counselling has been variously defined by different theologians. According to Hunter (1990), Christian Counselling is the practice of talking with individuals, couples, and families to increase their understanding of emotional and religious conflicts and to help resolve problems using Christian religious injunctions and other related resources. To Association of Christian Counsellors (ACC) (2019), Christian Counselling includes activities that "seek to help individuals towards constructive change and growth in any or every aspect of their lives, through a caring relationship and within agreed relational boundaries, carried out by a counsellor who has a Christian worldview, values and assumptions." In the opinion of Corona (2017), Christian Counselling offers clients an intersection of theological foundations, philosophical moral grounding, and evidence-based clinical skill applications. Christian Counsellors integrate modern psychological thought and method with traditional religious training in an effort to address psycho-spiritual issues in addition to the traditional spectrum of counselling services (Benner, 2003).

Christian Counselling uses both psychological and theological resources to deepen its understanding of the pastoral relationship (Hunter, 2005; Bernner, 2003). According to Christian Counselling (1994), Christian counselling seeks to bring the truth of the Scriptures to bear upon problems in the life of the person. It contains the therapeutic application of empathetic listening, discerning insight and practical strategies as well as the careful application of the Word of God directly or indirectly to the situations presented to the counsellor. Christian counselling involves a significant relationship with a genuine, compassionate individual. Together the client and the counsellor seek truth within the context of faith and then learn to apply such truth to daily living. Christian Counselling may include pastoral counselling, psychology, discipleship, training, therapeutic counselling, family counselling, career counselling, as well as other approaches to the helping process (Christian Counseling, 1994).

Counsellors view the world differently and thus use different methodologies or models for their counselling depending on their training and what they find to be effective. Christian Counsellors are those who have a Christian worldview. They do not make any assumptions or have any requirements about the client's beliefs and values, and will not press their faith onto clients (Association of Christian Counsellors, 2019). When considering the management of psychological disturbance, generally counsellors assist clients using traditional psychotherapy and other approaches to offer clients more effective ways to cope and strategies to facilitate change for issues such as anxiety, stress, depression and trauma. Christian Counselling uses these same methodologies but integrates the religious and spiritual aspects that are absent. A Christian Counsellor may draw upon a Christian understanding of grace and sin, but he or she will maintain a psychological understanding of the mental illness. Christian Counselling should not be confused with Biblical or Nouthetic Counselling as these counselling solely on the Bible and rejects the psychological framework that secular mental health counselling and Christian counselling use (Grace College Online, 2016). A Christian Counsellor might take a similar structured approach with a referral to any mental health professional health however, the client would also receive spiritual counselling. He or she may be urged to read certain scripture and to pray and meditate. Overall, the approach might still use the cognitive behavioural therapeutic philosophy but would add spiritual aspects such as grace, repentance and restoring relationships - to the healing process (Grace College Online, 2016).

Secular and faith-based counselling approaches offer treatment to individuals who are experiencing psychological disturbance. Since the middle of the 21 st century, Christian Counselling has integrated a Christian worldview with related and helpful aspects of psychology (Grace College Online, 2016). Though there is a wide variety of approaches within the integration movement, Nelson (2009) affirms that there is broad agreement among its members that Psychology and Christianity have the potential to illuminate each other.

\subsection{Assumptions of Christian Counselling}

According to Christian Counseling (1994), all truth is God's truth, wherever it may be found, but the Scriptures are the only infallible rule for faith, practice, discipleship and maturation. In addition to a right relationship with God, the scope of counselling includes aiding people in developing Biblically ordered relationships with themselves and others. Of a truth, man is created in the image of God, but his relationship to God, to others and his perception of the self can be marred by rebellion against God's authority and His nature. Hence, individuals may experience disturbance as a result of their personal sinful choices or the sinful choices of others (e.g. family and society). 
The Bible further posits that the roots of all emotional and physical disturbance are Adam's sin, manipulations by satanic powers and oppression. However, in the case that man's disturbance is caused or exacerbated by physiological imbalances, often the organic aspect of a disorder cannot be corrected by counselling alone but requires the attention of a medical specialist.

Since all disturbance is contrary to God's original and ultimate purpose for His people, God may choose to work with or without the use of human beings in the healing process and He may choose to work immediately. In situations in which man's view of God and his interpersonal relationships contaminated, he could be hindered from embracing the truths of Christ and his healing power.

\subsection{MESERON THERAPY AND BIBLICAL TEACHINGS: A JUXTAPOSITION}

In applying the Meseron approach, the Christian counsellor must recognize the following:

The Person of God: Meseron Therapy is hinged on the philosophy of "I can" (Awaritefe \& Ofovwe, 2007). This, however, does not remove the person of God from the equation rather it shows that the role of striving for change is man's. The Bible says that it is for man to make the plans but it is God's to direct him (Proverbs 16:9). Put differently, achieving the desired goal is a dual responsibility shared between God and man (1 Corinthians 3:7). As affirmed in Meseron Therapy the client must not only believe in him/herself that the desire is achievable but must trust in God to achieve it. Philippians 4:13 says I can do all things through Christ that strengthens me. It, however, does not leave everything to God while the person does nothing expecting a change. It acknowledges the person of God as the ultimate help, and giver of all things including life, will, intellect and ability of man to pursue the desired change. This does not negate the place of faith, however, faith in God must go with works. It is written in the scriptures that faith without work is dead (James 2:26). In other words, your faith is judged by the pursuit of it. Psalms 60:12 say that through God we shall do valiantly. Your work is what makes manifest your faith (James 2:17 -18).

The Word of God: The world was made and sustained by the Word of God (Genesis 1:1). The scriptures further tell us in Hebrews 11:3 that the Word of God coupled together, fixed and framed the world. The rule, therefore, is that everything came from the spoken word and, therefore, must be sustained by words and respond to words. The Bible is the documentation of the Word of God and the manual guiding man's relations to everything and everyone around him. To have good success, man must observe and do all that is written in the scriptures (Joshua 1:8). Christian counselling must, therefore, be centred on the Word of God. Therapeutic models that discountenance and disagrees with the basic truth and teachings of God's word, and is solely based on human reasoning and ideologies are not applicable to Christian Counselling. Meseron Therapy affirms the power in the spoken word and how an internalized word can affect the psychic of man either positively or negatively depending on thought process and attached interpretations. This underlying fact makes Meseron Therapy applicable to Christian counselling.

God's Plan for Man: Christian Counselling must be based on the plan of God for man. It must be noted that the calamities that befall man resulting in manifestation of psychological disturbance are not God's will or desires. In Jeremiah 29:11 God declared that His plan is for man's wellbeing and not for calamity for a glorious future and hope. God does not desire to afflict anyone; man is afflicted when they walk contrary to the principles established in the Word of God for healthy living. 3 John 1:3 says the wish of God above all things is for man to have all-round (physiological, psychological, social, material etc.) wholeness, peace, wellbeing and prosperity. Why then does affliction come? The answer is simply the wrong choices. Man constantly goes against principles guiding the laws of nature, morality, social interactions, laws of reciprocity and of seedtime and harvest to mention a few. When we make the wrong choices in diet and lifestyles, take more from others than we are willing to give, disrupt the delicate balance on which our world is created and sustained, set ourselves against the very principle designed to sustain us, the result is chaos. Christian Counselling, therefore, must strive to bring the client back to the plan of God through first identifying the disconnect from God's plan, followed by proper application of Biblical teachings to remove the conflict and discord with principles of nature thereby restoring health (physiological, psychological, social, material e.t.c.) to the client.

The Sinful Nature of Man: Made as the finest of all species and the crown of all creation of God, man is wired to live a stress-free and pleasant life, but for his sinful nature. Christian Counselling must not negate or gloss over the truth that in man's quest for freedom from the commands of God, man charted his own path which ends in separation from God's ideals resulting in stress, stagnancy, sickness, sorrow and other negative outcomes. Ezekiel 18:4 says that the soul that sins shall die. The sinful nature made man selfish in the pursuit of his vanities. Activities of gratifying the self do not care who gets hurt and in the process, wants that are insatiable are formed, pains of not always having things our way pile up, and plots to get rid of oppositions at all cost are designed and executed. Applauded by a self-serving and spiritually apathetic society, man runs contrary to his original nature and has become acquainted with diverse undesirable consequences. Therefore, Christian Counselling must confront clients with the truth that undesirable circumstances often result from the pleasures of sins not repented from. It must also emphasizes the inability of man to free himself from the promptings of Satan, the nature of sin, 
and the consequences of sinful acts without the help of God.

Redemptive Package/Solution in Christ: Christian Counselling must point to Christ as the solution provider to the sinful nature of man. According to Hess (2018), Christian Counselling must never become a science that denies God's power and help. It must keep God at the centre and not man and must never look at life outside the perspective of eternity. There are however certain approaches that do not emphasize God's power or help but have been found to align with key Biblical principles and have proven to be helpful in counselling (Hess, 2018). One of such is Meseron therapy. Hence the task of Christian counsellor is to use their understanding of the Bible, the psychological approach and a factual understanding of human behaviour to successfully combine both approaches in the effective counselling of their clients and in its application in their personal lives, as deemed fit. The Meseron approach has a lot in common with the basic biblical teachings making it easily adaptable to Christian Counselling. We will further consider the key views of the Meseron approach and their links with the Bible.

i. Meseron view of human nature

ii. Views on the causation of psychological disturbance

iii. The goals of Meseron Therapy

iv. Therapeutic techniques and procedures of Meseron Therapy

i. Meseron View of Human Nature

According to Meseron, the nature of man is to strive. The motivation and determination to better whatever he has and wherever he finds himself is innate in every man. This nature pushes man to invent and create things and environments that will bring out the best in him and this view of man has a very strong biblical base. When God created Adam, He placed him in a garden and instructed him to improve what he had been given (Genesis 2:15). Indeed, man loses the battles of life when they refuse to strive. Adverse situations abound and surround man, and man adversities are natural with man. Philippians 3:14, Psalm 2:8 and 1 Chronicles 4:10 encourage man to press towards a higher, better and wholesome life. In agreement with biblical teachings, Meseron approach views man as a striving creature who is under some compulsion to improve himself and influence his environment and thus be enabled to live a wholesome life.

Meseron also views man as being equipped with psychological instruments for striving known as man's perceptive capacity which plays the role of the awareness function making man aware of his current situation and environment. Another psychological instrument for striving available to man is his appraisal mechanism which has an interpretive function and enables man to appreciate the congruence or incongruence of his striving and his goal although man's striving may not always in consonance with his goals.

Additionally, in the view of human nature, Meseron posits that man has three core operational facilities which are his thoughts, words and actions (deeds). These operational facilities are in tandem with biblical teachings, and thus support the application of Meseron Therapy to Christian Counselling. The Bible teaches that human thought is the essence and centre of man. Proverbs 23:7 says that as a man thinks in his heart, so is he, supporting the Meseron approach which believes that faulty thoughts are central to man's psychological problems.

\section{ii. Views on the Causation of Psychological Disturbance}

Meseron Therapy theorizes that there are three major ways in which psychological disturbance may occur. These also have strong biblical agreement, credence, acceptance and applicability.

First, a distortion in appraisal mechanism. Biases in judgment or assessment of situations, people, or phenomenon may influence our dispositions and our behaviour both overt and covert. Distorted appraisal mechanism manifests in

a. Thinking negative thoughts and

b. Making negative statements

Biblical teachings also agree that the human thought process and the words spoken to or by man have a huge effect on wellbeing. For instance, in Philippians 4:8, the Bible teaches Christians to avoid negative thought patterns and embrace the positive thinking saying "keep your thoughts on whatever is right or deserves praise: things that are true, honourable, fair, pure, acceptable, or commendable". Also Romans 12: 17 says we should focus our thoughts on what is right in the sight of all people. Considering the impact of spoken words on wellbeing, the Bible is also in agreement with Meseron approach. For instance, Job 22:28 says "Thou shall decree a thing, and it shall be established unto thee”. Also, Jesus said in Mark 11:23 “ ....that whoever shall say to this mountain, be moved and be cast into the sea, and shall not doubt in his heart, but shall believe that what he said shall occur, he shall have whatever he said." Furthermore, Proverbs 18:21 says that there is both death and life in the tongue. These scriptures prove the efficacy of the power of spoken words to our psychic. Thus, making negative statements is often a reflection of that content of the thought process is equally negative resulting in psychological disturbance.

The second way through which psychological disturbance occurs is by acquiescing to negativity. This implies a resignation in the face of difficult situations. Meseron approach affirms that what you acquiesce to 
happens to you. Agreeing to negative leaves a person vulnerable and exposed to the possibility of manifestation of such negativities. It implies giving consent and opening up for the undesirable. Acquiescing to negativities is a reflection of the feeling of hopelessness and helplessness. There are also Biblical illustrations supporting this view. In the book of Numbers chapter 13, twelve men were sent to spy the promised land, on their return after forty days, ten of the men gave a negative report, in Verse 31 they said: "We are not able to go up against the people, for they are stronger than we." The nation of Israel who got the report, as well as the ten men that gave the report, were so acquiesced to the negative report that they suffered psychological disturbances manifesting in symptoms as poor self-concepts, poor self-esteem, weepy spells, feeling of hopelessness, group avolition, rebellion against authority, depression and suicidal ideation (Numbers 14:1-11). Based on this illustration the Christian and the Meseron approaches agree that what you acquiesce to comes to you.

The incongruence of striving and goals is the third way through psychological disturbance occurs. Man is a striving creature; however, this has to be goal-oriented for successful living. However, when striving is not in consonance with one's goals, psychological disturbances occur. The incongruence of striving and goals can take place in if unhelpful or counter-productive decisions are made, and /or if choices made are inappropriate. On a daily bases, man is faced with different choices as he pursues his goals. Unfortunately, many people out of ignorance, ill advice, and sometimes desperations make wrong choices or take counterproductive decisions which in most cases cause ripple effects that negatively affect the individual and many others at both the family societal level. Again this perspective is supported by Biblical teaching. In actual fact, the bible is a book that exposes choices between good and evil (Deuteronomy 28) and directs people on how to make the right decisions and choices (Deuteronomy 30:15). This appraisal shows common grounds between Meseron and Biblical approaches on the view of the causation of psychological disturbance.

iii. Goals of Meseron Therapy

The core goals of Meseron can be easily adopted in Christian Counselling. They are:

1. To foster the change of undesirable conditions

2. To bring about a change in counterproductive concept and values

3. To effect a change of bad habits

4. To get the client to strive effectively

5. To serve a preventive function for psychological disturbance, thus facilitating the maintenance of positive psychological health.

iv. Therapeutic techniques and procedures of Meseron Therapy

First, Meseron Therapy entails sustenance of good health by encouraging clients to use and maintain his/her endowments. Each individual has some talents and potentials that if not used will be lost. In 2 Timothy 1:6, Apostle Paul counselled Timothy to make use of his talents. Using related scriptural backings Christian Counselling can apply Meseron Therapy in helping clients realize his role in the determination of his fate through resilience, positive self-talk and a motivation to strive thus boosting the internal locus of control in the client.

Second, Meseron Therapy assists clients in mental restructuring by motivating clients to strive and promoting his use of inherent attributes while refusing the negatives. The Bible admonishes that a believer should not align himself to the societies negative stereotypes, but should instead be "...transformed by the renewing of your mind, that ye may prove what is that good, and acceptable, and perfect, will of God" (Romans 12:2). The Bible encourages mental restructuring which conforms to God's will for man. This, in essence, makes this Meseron technique applicable to Christian Counselling.

Third, Meseron Therapy technique aims to grow and encourage possibility thinking. One of the assumptions of Christian counselling is that through faith in God all things are possible. One main philosophy of Meseron Therapy is "I Can." Similarly, Philippians 4:13 says "I can do all things through Christ...." Thus Christian Counselling can apply this technique to promote self-efficacy and resilience in clients in order to solve their problems.

Another technique of Meseron Therapy is the empowerment of clients to reject distractions from goal accomplishment. Meseron approach establishes that incongruence of striving and goals results in psychological disturbance thus clients are trained to reject distractions. There are several Biblical teachings on reasons to focus on needful and most important things and avoid distractions (Luke 10:42, Philippians 3:13).

Lastly, Meseron gets the client to make positive self-talk while synergizing his thoughts, words and actions. It affirms positive self-talk that can bring about a change in cognition and action (behaviour) based on the belief that positive thoughts and words will empower clients to take appropriate actions. Also, Meseron Therapy teaches vehement rejection of negatives as well as dissociation from using it, not just in thoughts but their words and their actions.

\subsection{CONCLUSIONS}

The Meseron approach encourages constructive activity and not indolence or merely rejecting the negative. 
Nothing desirable occurs when a person fails to take charge of his life, and be part of the positive and creative forces in his environment. Meseron Therapy is not just a therapeutic method it is also a preventive approach to psychological disturbance hence making it applicable to everyday living. The techniques used in Meseron Therapy are in agreement with biblical teachings and are therefore suitable for Christian Counselling.

\section{REFERENCES}

Association of Christian Counselors (2019). What is Christian counselling? Retrieved from https://www.accuk.org/become-a-counsellor/what-is-christian-counselling.html

Awaritefe, A. (1995). Meseron Therapy. A paper presented at the first national conference on the practice of psychotherapy in Nigeria held at the Nigerian Institute of International Affairs, Victoria Island, Lagos, $6^{\text {th }}-$ $9^{\text {th }}$ November.

Awaritefe A., Akpunne B. C. \& Olarinoye D. (2018). The use Of African proverbs to motivate clients in Meseron Therapy. International Journal for Psychotherapy in Africa. ISSN: 2550-7257 (3)1

Awaritefe, A., \& Ofovwe, C. (2007). Meseron therapy: An African approach to psychological treatment. Ife PsychologIA; Vol 15 [2], $71-81$.

Benner, D. G. (2003). Strategic Pastoral Counseling: A Short-Term Structured Model. Grand Rapids MI: Baker Academic. pp. 13-14. ISBN 978-0801026317.

Christian Counseling (1994). The Christian counseling center of FIRST Presbyterian church INC January 31, 1994. Retrieved from https://www.christiancounseling.ws/about-us/theological-foundations/

Corona, A. (2017). Pastoral counseling applications, blog. Franciscan university Austria. Retrieved from https://blogs.franciscan.edu/pastoral-counseling-applications

Grace College Online (2016). Biblical foundations in therapy: Exploring christian counseling. Retrieved from https://online.grace.edu/news/ministry/exploring-christian-counseling/

Hess, L. G. (2019). The techniques of counseling. Retrieved from http://www.faithlibrary.cc/index.php/christiansermons/sermon/the techniques_of_counseling

Hunter, R. J. (2005). Pastoral Counseling. Dictionary of Pastoral Care and Counseling. Nashville: Abingdon Press. ISBN 0-687-10761-X

Hunter, R. J. (1990). Dictionary of Pastoral Care and Counseling. Abingdon Press; 3rd edition

Nelson, J. M. (2009). Psychology, Religion, and Spirituality. Springer 2009 edition 